\title{
Mississippian (Lower Carboniferous) miospores from the Cuyahoga and Logan formations of northeastern Ohio, USA
}

\author{
GEOFFREY CLAYTON, ${ }^{i}$ WALTER L. MANGER ${ }^{2}$ \& BERNARD OWENS ${ }^{3}$ \\ ${ }^{1}$ Department of Geology, Trinity College, Dublin 2, Ireland. \\ ${ }^{2}$ Department of Geology, University of Arkansas, Fayetteville, AR 72701, USA. \\ ${ }^{3}$ British Geological Survey, Keyworth, Nottingham NG12 5GG, UK.
}

\begin{abstract}
Well-preserved Lower Mississippian (Dinantian) miospore assemblages have been recovered from the upper Cuyahoga Formation (type Wooster Member) and overlying lower Logan Formation (Byer Member) at two localities in Wayne County, northeastern Ohio, USA. All six samples were productive and yielded assemblages that represent the middle Tournaisian Spelaeotriletes pretiosusRaistrickia clavata (PC) Miospore Biozone of Western Europe including a new species of trilete, acamerate miospore, Mooreisporites streelii, described from the Wooster Shale. Significant numbers of latest Devonian and earlier Carboniferous miospores are reworked into all assemblages. The palynological evidence is consistent with a late Kinderhookian age for most of the Cuyahoga Formation, including its well known ammonoid fauna. However, the position of the boundary between the Kinderhookian and Osagean Series remains uncertain. J. Micropalaeontol. 17(2): 183-191, December 1998.
\end{abstract}

\section{INTRODUCTION}

The stratigraphic interval extending from the Ohio Shale to the base of the Sharon Conglomerate of the Pottsville Group, has been referred historically to the Waverly Group (Briggs, 1838) and divided, in ascending order, into the Bedford Shale, Berea Sandstone, Sunbury Shale, Cuyahoga Formation, Logan Formation and Maxville Limestone (Collins, 1979). In spite of considerable recent progress, the age and correlation of this succession, particularly surrounding the Bedford-Berea and Cuyahoga-Logan formations, remain controversial. Contradictory statements concerning assignments for the component formations permeate the literature. This situation is well illustrated by Waverly Group correlations on the charts produced for the Correlation of Stratigraphic Units of North America Project (COSUNA). The Northern Appalachian Region Chart (Patchen et al., 1985a), which includes eastern Ohio, places the entire Waverly succession in the Lower Mississippian (columns 15, 16 \& 20), and locates the Kinderhookian-Osagean boundary within the upper Logan Formation, or at its top, where erosion has removed the younger Logan interval. A similar age assignment and correlation is recorded for the interval on the Southern Appalachian Region Chart (Patchen et al., 1985b, column 16), which includes a small portion of south central Ohio that comprises the drainage basin of the Scioto River. In contrast, the conterminous Midwestern Basin and Arches Region COSUNA chart (Shaver, 1985, columns 16 \& 18) includes adjacent western Ohio and places the Devonian-Mississippian boundary within the Bedford Shale and the Kinderhookian-Osagean boundary within the upper Cuyahoga Formation. In none of these charts is there any suggestion that any of the lithostratigraphic boundaries of Waverly formations are time transgressive. The stratigraphy of the region is summarized in Fig. 1.

\section{LITHOSTRATIGRAPHY}

Lower Mississippian rocks crop out in an arcuate band across central and northeastern Ohio. The sections in Wayne County, Ohio investigated in this study are restricted to the upper Cuyahoga and lower Logan formations (Fig. 2). The Cuyahoga

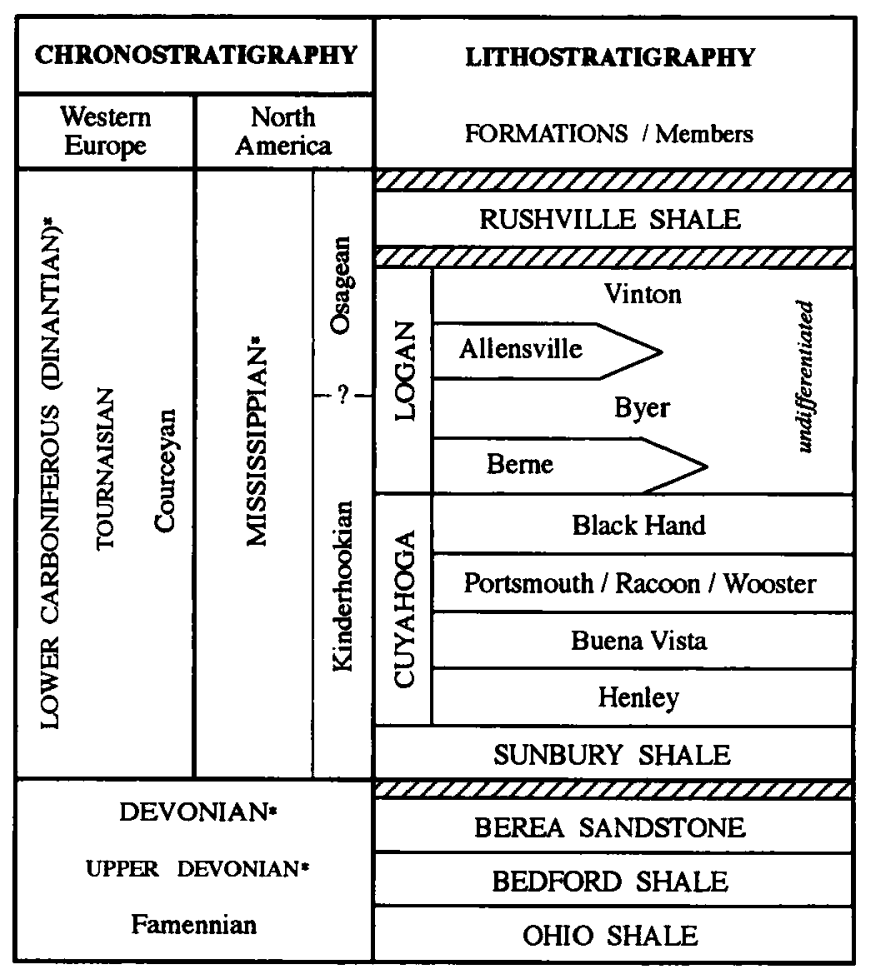

Fig. 1. Stratigraphic summary of the Upper Devonian and Lower Mississippian in northeastern Ohio.

Formation (Newberry, 1870) is a deltaic complex, characterized by prodeltaic and interdistributary shales and siltstones, and coeval distributary channel quartz sandstones and conglomerates. A plethora of lithostratigraphic members has been proposed to differentiate laterally equivalent shale and siltstone successions that were deposited between, but occasionally eroded by, lobes of conglomeratic sandstone (Holden, 1942; Collins, 1979). In Wayne County, the upper Cuyahoga distributary channel facies is referred to the Black Hand Sandstone (Hicks, 1878) and the interdistributary facies is called 


\section{'LITTLE ARIZONA'}
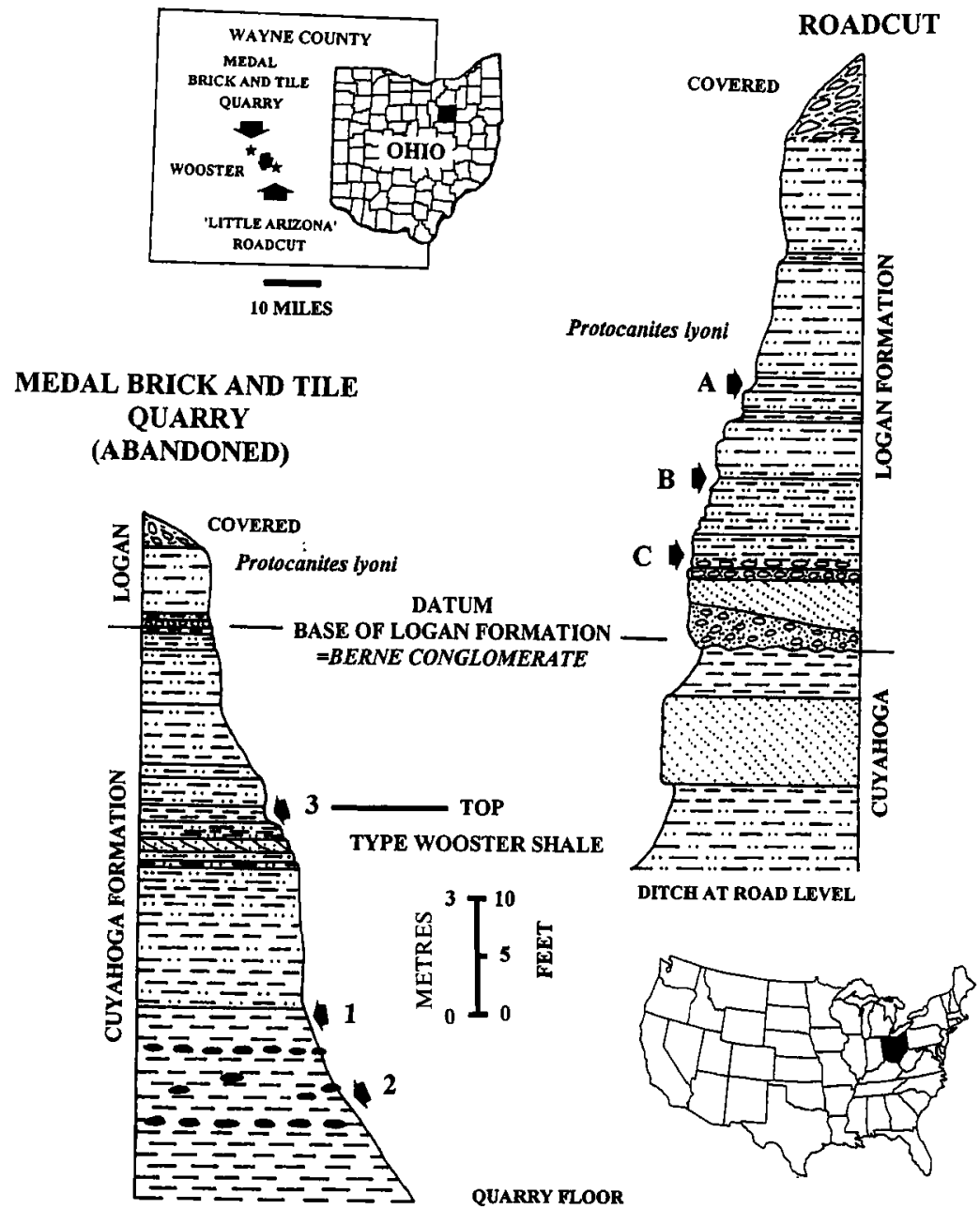

Fig. 2. Location and stratigraphy of the sections investigated.

the Wooster Shale (Szmuc, 1957, 1970). Black Hand lithologies lack marine fossils, while the Wooster Shale has a normal marine invertebrate assemblage usually associated with sideritic concretionary intervals in this dark gray, silty shale. Maximum thickness and coarsest grain sizes of the Black Hand Member occur in its type area, central Ohio, where the member approaches $70 \mathrm{~m}$. It thins to less than $13 \mathrm{~m}$ throughout most of Wayne County, and is only c. $3.25 \mathrm{~m}$ at the Medal Brick and Tile Quarry (Locality 2). Elsewhere, the Black Hand Member pinches out and is represented by interdistributary shales. Maximum thicknesses for the Wooster Member vary from 20$30 \mathrm{~m}$, and it is persistent throughout most of northeastern Ohio.

The overlying Logan Formation (Andrews, 1870) is an alternation of fine sandstone-siltstone intervals with thin $(<1 \mathrm{~m})$, but persistent, quartz pebble conglomerates and lacks significant shales. Lithostratigraphic nomenclature recognizes the Berne (basal) and Allensville conglomerate members separating the Byer and Vinton members of essentially identical, fine-grained lithology. The conglomeratic Berne Member has been included in the Cuyahoga Formation (Collins, 1979), but its thickness and lithologic variation can be related to reworking of the underlying Black Hand Member, which supports its recognition as the base of the Logan Formation (Szmuc, 1970; Manger, 1971a). Thus, there is an unconformable boundary between the Cuyahoga and Logan formations, particularly at localities where the Black Hand Member is developed, but the contact is diastematic and below biostratigraphic resolution. Maximum thickness of the Logan Formation may exceed $100 \mathrm{~m}$ in southern Ohio, where both the Berne and Allensville conglomerates pinch-out, and the Logan is not subdivided. Logan deposition represents establishment of a shallow marine shelf over the drowned Cuyahoga delta.

\section{PREVIOUS BIOSTRATIGRAPHIC WORK}

Mississippian Series chronostratigraphy is based on exposures along the Mississippi River where it separates Missouri and Illinois in the North American mid-continent, with the exception of the Osagean Series, which has been derived from exposures in southwestern Missouri. Stratotype sections have not been designated and the biostratigraphic framework supporting this classification is based primarily on conodont zonations developed during the decade of the 1960s (Collinson et al., 1971). 


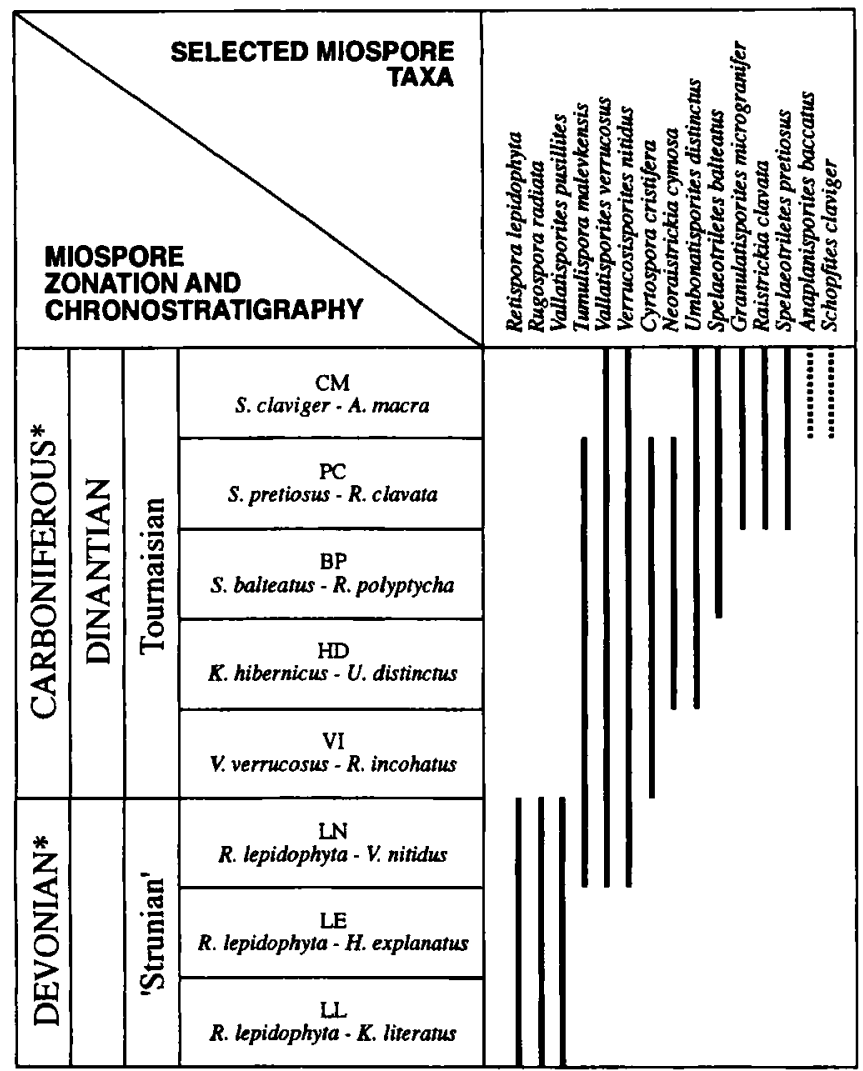

Fig. 3. Stratigraphic ranges in Western Europe of selected miospore species recorded in the Ohio samples (key taxa not recorded in the Ohio samples are shown by dashed lines: ${ }^{*}=$ in part).

Ammonoid cephalopods are notably absent in these sections and the predominance of carbonate lithologies has precluded palynomorph recovery, although a zonal scheme based on calcareous foraminifers is well known. Mississippian biostratigraphic correlations from those same sections were accomplished mainly by brachiopods earlier in this century (e.g. Weller et al., 1948) and more recently the COSUNA program has reviewed and revised many of these assignments, although the

Table 1. Distribution of miospore taxa and other selected palynomorphs The authors of the taxa listed are: 1. Playford, 2. Neves \& Ioannides, 3 Loboziak, Clayton \& Owens, 4. Sullivan, 5. Hoffmeister, Staplin \& Malloy, 6. (Loose) Schopf, Wilson \& Bentall, 7. (Kedo) Turnau, 8. Hoffmeister, Staplin \& Malloy, 9. Hughes \& Playford, 10. (Knox) Sullivan, 11. (Luber) emend van der Zwan, 12. Playford \& Satterthwait, 13. (Hacquebard) Sabry \& Neves, 14. Hacquebard emend Utting, 15. Ibrahim, 16. (Waltz) Playford, 17. Hoffmeister, Staplin \& Malloy sensu Sullivan 1964, 18. (Waltz) Ischenko, 20. Higgs, Clayton \& Keegan, 21. (Winslow) Coleman \& Clayton, 22. (Winslow) Coleman \& Clayton, 23. Hughes \& Playford, 24. (Higgs) Higgs, Clayton \& Keegan, 25. Kosanke, 26. Hacquebard, 27. Higgs, Clayton \& Keegan, 28. Hacquebard emend Playford, 29. Playford sensu Coleman \& Clayton 1987, 30. (Kedo) Playford, 31. Sullivan, 32. (Streel) Streel, 33.(Kedo) Byvscheva, 34 (Playford) Higgs, 35. (Playford) Higgs, Clayton \& Keegan, 36. (Playford) Neves \& Belt, 37. Hacquebard, 38. (Kedo) Turnau, 39 (Luber) Playford, 40. (Playford) Clayton, 41. Clayton, 42. (Kedo) Dolby \& Neves, 43. Hacquebard, 44. Hacquebard, 45. Playford, 46. (Naumova) Playford.

\begin{tabular}{|c|c|c|c|c|c|c|c|}
\hline 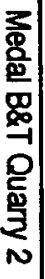 & 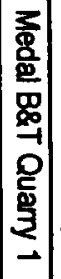 & 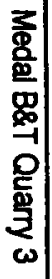 & 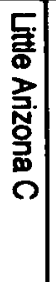 & 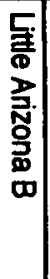 & 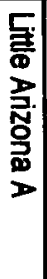 & $\frac{\mathscr{0}}{\mathscr{3}}$ & \\
\hline \multirow[t]{3}{*}{$x$} & $\bar{x}$ & $x$ & & & & Anapiculatisporites hystricosus & 1 \\
\hline & $x$ & & $x$ & & & Anaplanisporites atheticus & 2 \\
\hline & & & & & $x$ & Aratrisporites saharaensis & 3 \\
\hline \multirow[t]{3}{*}{$x$} & $x$ & & & & & Auroraspora macra & 4 \\
\hline & & & $x$ & & & Auroraspora solisorta & 5 \\
\hline & & & & $x$ & & Calamospora pallida & 6 \\
\hline$\times$ & & & & & $\times$ & Convolutispora major & 7 \\
\hline$\times$ & $x$ & & & & & Convolutispora cf. mellita & 8 \\
\hline$x$ & $\underline{x}$ & $x$ & & $x$ & $x$ & Convolutispora vermiformis & 9 \\
\hline$x$ & & & & & & Crassispora maculosa & 10 \\
\hline \multirow[t]{3}{*}{$\times$} & & & & & & Cyrtospora cristifera & 11 \\
\hline & & & & $x$ & & Cordylosporites marciae & 12 \\
\hline & & & & $\times$ & & Discernisporites micromanifestus & 13 \\
\hline \multirow[t]{2}{*}{$x$} & & $x$ & & $x$ & $x$ & Grandispora echinata & 14 \\
\hline & & & & & $x$ & Granulatisporites microgranifer & 15 \\
\hline \multirow[t]{3}{*}{$x$} & & & & & $x$ & Knoxisporites literatus & 16 \\
\hline & & & & $\times$ & $x$ & Knoxisporites of. triradiatus & 17 \\
\hline & & & & $x$ & & Leiotriletes inermis & 18 \\
\hline$x$ & $x$ & $x$ & & & $x$ & Mooreisporites streelii sp. nov. & 19 \\
\hline \multirow[t]{3}{*}{$\times$} & & & & & & Neoraistrickia cymosa & 20 \\
\hline & & $x$ & $x$ & $x$ & & Neoraistrickia logani & 21 \\
\hline & & & & $x$ & & Mooreisporites sp. cf. N. logani & 22 \\
\hline \multirow[t]{2}{*}{$\bar{x}$} & $x$ & & $x$ & & & Perotrilites magnus & 23 \\
\hline & & & & $x$ & & Plicatispora quasilabrata & 24 \\
\hline \multirow[t]{2}{*}{$\bar{x}$} & $\bar{x}$ & & $x$ & $x$ & & Punctatisporites minutus & 25 \\
\hline & & $x$ & $\bar{x}$ & & $x$ & Punctatisporites planus & 26 \\
\hline \multirow[t]{2}{*}{$x$} & $x$ & $x$ & $x$ & $x$ & $\times$ & Pustulatisporices dolbii & 27 \\
\hline & $x$ & & & $x$ & $x$ & Raistrickia clavata & 28 \\
\hline$x$ & & & & $x$ & $x$ & Raistrickia cf. strumosa & 29 \\
\hline$x$ & $x$ & $\times$ & $x$ & $x$ & $x$ & Retispora lepidophyta & 30 \\
\hline \multirow[t]{3}{*}{$x$} & & & $x$ & $x$ & $x$ & Remusotriletes incohatus & 31 \\
\hline & & & & & $x$ & Retusotriletes triangulatus & 32 \\
\hline & & & & $x$ & & Rugospora radiata & 33 \\
\hline$x$ & $x$ & $\times$ & $x$ & $x$ & $x$ & Spelaeotriletes balteatus & 34 \\
\hline$x$ & $x$ & & & & & Spelaeotriletes crenulatus & 35 \\
\hline$x$ & $x$ & $\mathbf{x}$ & $x$ & $x$ & $x$ & Spelaeotriletes pretiosus & 36 \\
\hline$x$ & $x$ & & & $x$ & $x$ & Spinozonotriletes uncatus & 37 \\
\hline \multirow[t]{2}{*}{$x$} & $x$ & & & & & Tumulispora malevkensis & 38 \\
\hline & & & & $x$ & & Tumulispora rarituberculata & 39 \\
\hline$x$ & & & $\times$ & & & Umbonatisporites abstrusus & 40 \\
\hline \multirow[t]{2}{*}{$x$} & $x$ & $x$ & \begin{tabular}{|l|l}
$x$ \\
\end{tabular} & $x$ & $x$ & Umbonatisporites distinctus & 41 \\
\hline & $x$ & $\times$ & & & & Vallatisporites pusillites & 42 \\
\hline$x$ & $x$ & & & & & Vallatisporites vallatus & 43 \\
\hline \multirow[t]{2}{*}{$x$} & $x$ & $\times$ & $x$ & $x$ & $x$ & Vallatisporites verrucosus & 44 \\
\hline & $x$ & $\times$ & & & & Verrucosisporites congestus & 45 \\
\hline$x$ & $x$ & $x$ & $x$ & $x$ & $x$ & Verrucosisporites nitidus & 46 \\
\hline$x$ & $\bar{x}$ & & & & & BOTRYOCOCCUS & \\
\hline \multirow[t]{3}{*}{$x$} & $\bar{x}$ & & $x$ & $x$ & $x$ & ACRITARCHS & \\
\hline & $x$ & & $\bar{x}$ & $\times$ & & TASMANITIDS & \\
\hline & & & & $x$ & & SCOLECODONTS & \\
\hline
\end{tabular}

Table 1. 
basis for these correlations is not reported.

The Cuyahoga and Logan formations have been regarded as Lower Mississippian from their inception (Newberry, 1870; Andrews, 1870) but there has never been agreement surrounding placement of the Kinderhookian-Osagean boundary, although most assignments have regarded that formational boundary interval as falling within the Osagean Series (e.g. COSUNA charts). The current iteration of the problem results from analysis of ammonoid assemblages from Kentucky, Michigan, Ohio, and the western United States, in particular the significance of occurrences of the genera Muensteroceras and Protocanites. The controversy has been reviewed by Manger (1971a, 1979), Gordon \& Mason (1985) and Gordon (1986). Resolution of the controversy is confounded by: (1) lack of ammonoid assemblages in the type areas for the Kinderhookian and Osagean Series; (2) occurrences frequently consisting of single specimens with minimal stratigraphic data; (3) lack of integration of occurrence data for Kinderhookian and Osagean conodonts and ammonoids; (4) lack of conodonts from the Cuyahoga and Logan Formations; (5) endemic distribution of most Lower Mississippian ammonoid species in North America; (6) lack of biostratigraphic sensitivity to the series boundary for most ammonoid genera; (7) pronounced time-transgressive depositional settings in Kentucky, Ohio and Michigan; and (8) perpetuation of correlations based on out-dated and/or poorly constrained biostratigraphic data. Assessments of the Kinderhookian-Osagean ammonoid occurrences have reached the point of circularity, and it seems now that the only hope of resolving problems surrounding boundary placement is an appeal to some other biostratigraphically sensitive group, for example, miospores.

Unfortunately, previous palynological studies of Mississippian sediments in North America have been restricted to relatively short stratigraphic intervals and most have concentrated on placement of the Devonian-Mississippian boundary (e.g. Winslow, 1962; Warg \& Traverse, 1973; Streel \& Traverse, 1978; Molyneux et al., 1984). No comprehensive zonation for the system exists for North America. All recent palynological studies have relied extensively on the miospore zonation that has been developed from well documented sections in Western Europe (Clayton et al., 1977) but provincial chronostratigraphic divisions, such as the Kinderhookian-Osagean boundary, have never been fully investigated.

The most extensive palynological study available for comparison with the Cuyahoga-Logan assemblages reported herein is that of Coleman \& Clayton (1987), who investigated the uppermost Devonian and lower Mississippian sequence in eastern Kentucky. The Bedford Shale yielded an assemblage representing the Western European Late Devonian LN Biozone
(Clayton et al., 1977), while the Sunbury Shale contains an assemblage referable to the earliest Carboniferous VI Biozone (Clayton et al., 1977), equivalent to upper Tournaisian 1b. Thus, the Devonian-Mississippian boundary is placed with confidence at the Bedford Shale-Sunbury Shale contact. This placement is compatible with the recovery of Siphonodella conodont assemblages from the Sunbury Shale in both Ohio and Kentucky (Hass, 1947; DeWitt, 1970; Chaplin \& Mason, 1979; see following discussion). It is worth noting that while the Bedford Shale has been referred traditionally to the Lower Mississippian (e.g. DeWitt, 1970; Collins, 1979; Patchen et al., 1985a, 1985b), there is no biostratigraphic evidence to support this assignment; all biostratigraphic data indicate that the Bedford Shale is everywhere Late Devonian, and probably the Berea Sandstone is as well.

In eastern Kentucky, the Sunbury Shale is succeeded by the Borden Formation. Samples from its four lower members [in ascending order: Henley, Farmers, Nancy and Cowbell (Chaplin, 1979)], produced palynomorph assemblages belonging to the middle Tournaisian PC Biozone of western Europe (Coleman \& Clayton, 1987). There was no record of the intervening HD and BP Biozone microfloras, which, if present, would be represented presumably in the basal Henley bed that was barren.

\section{SAMPLE MATERIAL AND PREPARATION}

The material investigated was collected in 1988 by one of us (W.L.M.) from two localities close to the town of Wooster in Wayne County, Ohio. Location, lithologic successions and sampled horizons are shown on Fig. 2. These two sections were selected for study because both have produced the ammonoid cephalopod Protocanites lyoni, which has figured prominently in the controversy surrounding placement of the KinderhookianOsagean boundary in North America (Manger, 1979; Gordon, 1986).

\section{Locality 1 - 'Little Arizona' Roadcut.}

$\mathrm{Nl} / 2 \mathrm{NWl} / 4$, sec. $11, \mathrm{~T} .15 \mathrm{~N}, \mathrm{R} .13 \mathrm{~W}$.

Wooster 71/2' quadrangle (1961).

All samples from the Byer Member, Logan Formation.

Sample A: Shale layer $4.75 \mathrm{~m}$ above top of Berne Member.

Sample B: Bedding plane shale $3 \mathrm{~m}$ above top of Berne Member. Sample C: Bedding plane shale immediately above top of Berne Member.

Locality 2 - Medal Brick and Tile Quarry (Abandoned). $\mathrm{SWl} / 4 \mathrm{NE} 1 / 4$, section 5, T. $15 \mathrm{~N}, \mathrm{R} .13 \mathrm{~W}$.

Trinity College Dublin Geological Museum catalogue numbers are followed by sample and slide numbers and England Finder Co-ordinates. fig. 1. Retusotriletes incohatus Sullivan (TCD 47490) Little Arizona B(3), O 33/2. fig. 2. Umbonatisporites abstrusus (Playford) Clayton (TCD 47491) Medal B. and T. Quarry 2(4), K 35/0. figs 3 and 4. Verrucosisporites nitidus (Naumova) Playford. fig. 3. (TCD 47492) Medal B. and T. Quarry 1(3),M 49/3, Fig. 4. (TCD 47493) Medal B. and T. Quarry 2(2), M 44/0. fig. 5. Raistrickia cf. strumosa Playford sensu Coleman \& Clayton 1987 (TCD 47494) Little Arizona B(2), X 60/4. fig. 6. Mooreisporites sp. cf. Neoraistrickia logani (Winslow) Coleman \& Clayton (TCD 47495) Little Arizona B(3), Y 62/0. figs 7 and 11. Convolutispora major (Kedo) Turnau fig. 7 (TCD 47496) Medal B. and T. Quarry 1(4), R 34/0, fig. 11 (TCD 47500) Little Arizona A(1), T 46/3. fig. 8. Raistrickia clavata Hacquebard emend Playford (TCD 47497) Little Arizona B(3), S 46/0. fig. 9. Neoraistrickia logani (Winslow) Coleman and Clayton (TCD 47498) Little Arizona B(3), W 32/2. fig. 10. Neoraistrickia cymosa Higgs, Clayton \& Keegan (TCD 47499) Medal B. and T. Quarry 2(1), O 71/0. fig. 12. Crassispora maculosa (Knox) Sullivan (TCD 47501) Medal B. and T. Quarry 2(5), M 56/4. 

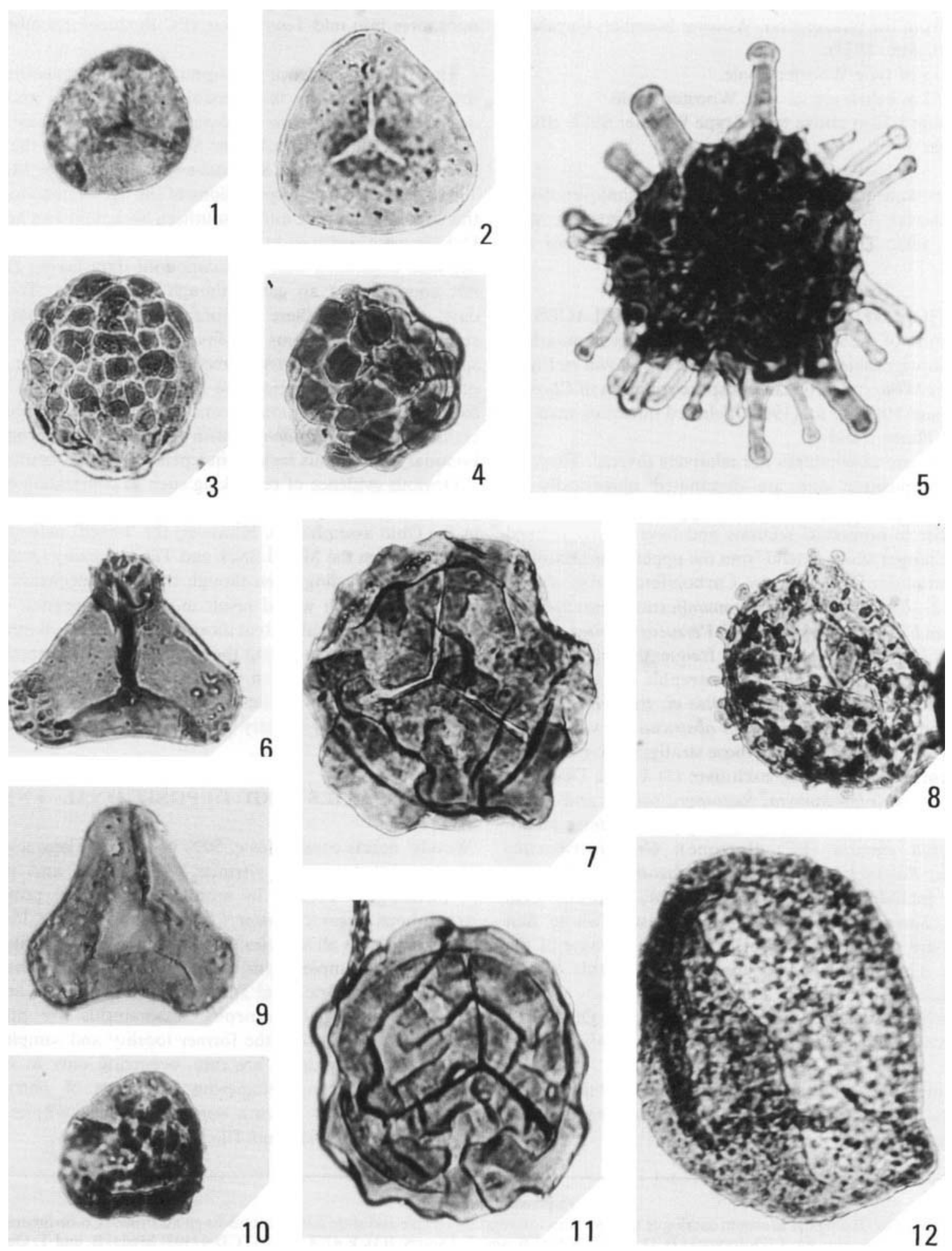

$50 \mu \mathrm{m}$

Plate 1 
Wooster 71/2' quadrangle (1961).

All samples from the type section, Wooster Member, Cuyahoga Formation (Szmuc, 1957).

Sample 1: Top of type Wooster Shale.

Sample 2: $1.52 \mathrm{~m}$ below top of type Wooster Shale.

Sample 3: Shale $1.52 \mathrm{~m}$ above top of type Wooster Shale (Black Hand Member).

All samples were prepared using standard techniques involving the removal of silica and silicates by treatment with hydrofluoric acid. The organic residues extracted were not oxidized.

\section{COMPOSITION OF THE MIOSPORE ASSEMBLAGES}

The composition of the six miospore assemblages is summarized in Table 1. Stratigraphic ranges of key taxa are shown in Fig. 3 in terms of the Western European miospore zonation of Clayton et al. (1977) and Higgs et al. (1988). Selected miospore taxa are illustrated in Plates 1 and 2.

All six miospore assemblages are relatively diverse. They are similar in composition and are dominated numerically by Vallatisporites spp. and Spelaeotriletes spp. Many of the taxa recorded occur in numerous sections and have clearly defined stratigraphic ranges which extend from the uppermost Devonian into the Tournaisian Series of the Carboniferous, e.g. Auroraspora macra, Discernisporites micromanifestus, Knoxisporites literatus, Tumulispora malevkensis and Verrucosisporites nitidus. Others which have been recorded less frequently and therefore have rather poorly documented stratigraphic ranges include Convolutispora vermiformis, Knoxisporites cf. triradiatus, Neoraistrickia logani and Umbonatisporites abstrusus. However, two further groups of taxa are present whose stratigraphic ranges are normally regarded as mutually exclusive: (1) Latest Devonian 'Strunian': Retispora lepidophyta, Rugospora radiata and Vallatisporites pusillites. (2) Mid-Tournaisian (Spelaeotriletes pretiosus-Raistrickia clavata (PC) Biozone): Granulatisporites microgranifer, Raistrickia clavata and Spelaeotriletes pretiosus. Other taxa including Convolutispora major, Neoraistrickia cymosa and Spelaeotriletes balteatus are present whose first appearances are Carboniferous but lower than the base of the PC Biozone. Three explanations are possible for this 'anomalous' association of taxa in the Ohio assemblages:

(1) The early (latest Devonian) first appearance in Ohio of $C$. major, G. microgranifer, N. cymosa, $R$. clavata, $S$. balteatus and S. pretiosus.

(2) The late (mid-Tournaisian) extinction in Ohio of the parent plants of Retispora lepidophyta, Rugospora radiata and Vallatisporites pusillites.
(3) Reworking of significant numbers of latest Devonian miospores into mid-Tournaisian (PC Biozone) assemblages.

There is no evidence to support the first hypothesis. The second explanation is plausible in view of 'anomalous' occurrences of Retispora lepidophyta in many sections in North America, including the Upper Shale Member of the Bakken Formation of southern Saskatchewan (Playford \& McGregor, 1993). The various interpretations of the age of conodonts from this lithostratigraphic unit in southern Saskatchewan and North Dakota were reviewed by Playford \& McGregor (1993, pp. 4748) who concluded that 'The conodont data favour (although not conclusively) an early, though not earliest, Tournaisian date...' However, these authors also concluded that circumstantial evidence seems to favour the conclusion that the specimens of $R$. lepidophyta recorded from the upper member of the Bakken Formation are recycled, though they note the circularity of the argument concerning the correlation of the extinction of $R$. lepidophyta with the Devonian/Carboniferous boundary in sections lacking independent faunal control.

Obvious evidence of reworking such as contrasting colour or state of preservation of the two miospore populations is absent in the Ohio assemblages. However, the 'mixed' palynofacies of sample 2 from the Medal Brick and Tile Company Quarry tends to indicate recycling, even though transport mechanisms could be invoked which would result in the incorporation of freshwater and ?lagoonal palynomorphs in marine sediments. The authors consider reworking the most probable interpretation of the miospore association and therefore conclude that the assemblages from both the Little Arizona and the Medal Brick and Tile Company Quarry sections are mid-Tournaisian (PC Biozone) in age.

\section{PALYNOFACIES AND DEPOSITIONAL ENVIRON- MENTS}

'Woody' debris constitutes $c .50 \%$ of the total kerogen content of the samples, with vitrinite (= hylogen) and inertinite (= melanogen) present in more or less equal proportions. Amorphous organic matter (= amorphogen) is $<1 \%$ of the total kerogen in all samples. Small acanthomorph acritarchs are present in all samples from Little Arizona, and samples 1 and 2 from the Medal Brick and Tile Company Quarry but are always $<1 \%$ of total palynomorphs. Tasmanitids are present in samples $B$ and $C$ from the former locality and sample 1 from the latter. Scolecodonts are rare, occurring only in sample B from Little Arizona. Numerous fragments of Botryococcus, some quite large $(>50 \mu \mathrm{m})$, were recorded in samples 1 and 2 from the Medal Brick and Tile Company Quarry.

Explanation of Plate 2

Trinity College Dublin Geological Museum catalogue numbers are followed by sample and slide numbers and England Finder Co-ordinates. figs 1-3. Mooreisporites streelii sp. nov. fig. 1 (Holotype) (TCD 47502) Medal B. and T. Quarry 1(3), E 47/4, fig. 2 (TCD 47503) Medal B. and T. Quarry 1(3), T 42/2, fig. 3 (TCD 47504) Medal B. and T. Quarry 2(2), U 60/4. fig. 4. Cyrtospora cristifera (Luber) emend Van der Zwan (TCD 47505) Medal B. and T. Quarry 2(3), H 41/2. fig. 5. Tumulispora malevkensis (Kedo) Turnau (TCD 47506) Medal B. and T. Quarry 1(1), E 39/4. fig. 6. Tumulispora rarituberculatus (Luber) Turnau (TCD 47507) Little Arizona B(2), R 37/2. fig. 7. Spelaeotriletes crenulatus (Playford) Higgs, Clayton and Keegan (TCD 47508) Medal B. and T. Quarry 1(1), F 49/3. fig. 8. Knoxisporites cf. triradiatus Hoffmeister, Staplin \& Malloy sensu Sullivan 1964 (TCD 47509) Little Arizona A(8), N 47/2. fig. 9. Rugospora radiata (TCD 47510) Little Arizona B(3), Q 49/0. figs 10 and 12 . Retispora lepidophyta (Kedo) Playford. fig. 10 (TCD 47511) Little Arizona B(3), V 33/0, fig. 12 (TCD 47512) Little Arizona B(1), Q 41/3. fig. 11. Spelaeotriletes balteatus (Playford) Higgs (TCD 47514) Little Arizona B(1), E 40/2. fig. 13. Spelaeotriletes pretiosus (Playford) Neves and Belt (TCD 47513) Little Arizona B(1), E 40/2. fig. 14. Vallatisporites vallatus Hacquebard (TCD 47515) Medal B. and T. Quarry 1(2), L 45/1. fig. 15. Vallatisporites verrucosus Hacquebard TCD (47516) Medal B. and T. Quarry 1(4), W 48/0. 

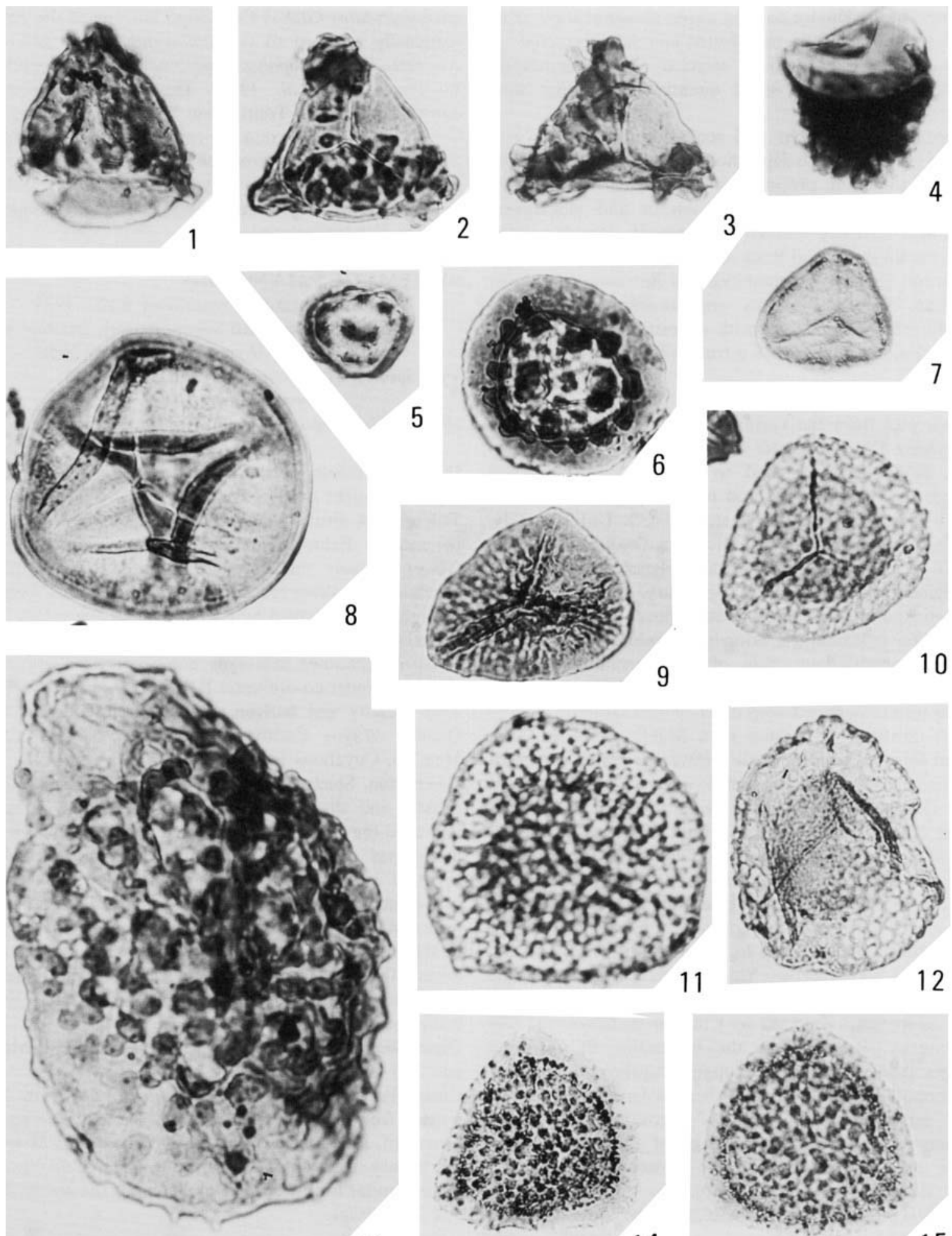

13

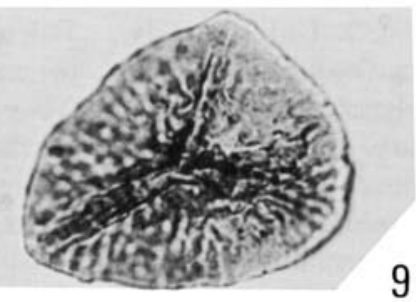

10
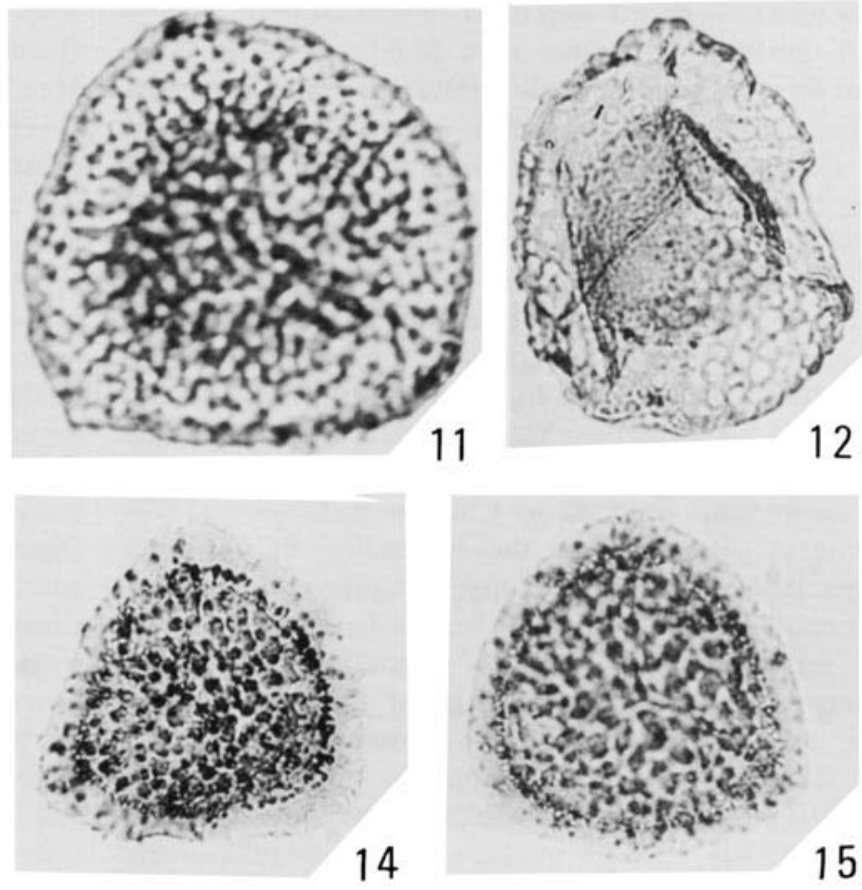

$50 \mu \mathrm{m}$

Plate 2 
Miospores are generally well preserved, though $1-10 \%$ of spore exines in all samples contain pyrite euhedra; there is no obvious correlation between pyritization and the interpreted age of the spores (i.e. indigenous or recycled). Miospore tetrads, megaspore fragments and small quantities of cuticle were recorded from all samples.

The records of acritarchs and scolecodonts together with pyritization suggest marine depositional and diagenetic environments. The dominant proportions of land-derived kerogen material and presence of miospore tetrads and megaspores indicate a nearshore depositional environment. The association in sample 1 from the Medal Brick and Tile Company Quarry of acanthomorph acritarchs, tasmanitids and Botryococcus suggest fully marine, abnormal salinity and freshwater conditions, respectively. This is consistent with deposition in an interdistributary setting associated with a true deltaic environment.

\section{DISCUSSION}

The six samples from the Cuyahoga and Logan Formations from northern Ohio reported in this study have produced miospore assemblages assigned to the PC Biozone which corresponds in Europe to the mid to early upper part of the Courceyan Stage (late 'Tn2' and early 'Tn3'). Unfortunately, this biozone also spans the Kinderhookian-Osagean boundary in Ohio. In spite of the lack of a precise palynological definition for the Kinderhookian-Osagean boundary, recovery of PC Biozone miospore assemblages both above and below the Cuyahoga-Logan Formation boundary significantly limits the interval for potential placement of that chronostratigraphic boundary and increases the precision of correlation for those formations when integrated with other biostratigraphic data.

There is universal acceptance of a Middle Kinderhookian assignment for the Sunbury Shale. However, conodonts (most notably Siphonodella duplicata and $S$. quadrupilicata) reported by Hass (1947) from the Shale were not figured. Recent refinement of the Siphonodella zonation recognizes two morphotypes of S. duplicata that must be differentiated for confident zonal placement (Sandberg et al., 1978). Nevertheless, the Sunbury Shale represents some or perhaps all of three global conodont zones (i.e. Lower $S$. duplicata, Upper duplicata and sandbergi ) that are equivalent to Tournaisian (Tnlb) and the middle Kinderhookian Series. That correlation is compatible with the age assignment based on the associated VI Biozone miospore assemblages reported by Coleman \& Clayton (1987) from Kentucky. Recovery of the succeeding PC Biozone assemblages from the overlying upper Cuyahoga and lower Logan Formations in Ohio and the Borden Formation in Kentucky demonstrates continuity of deposition through the entire interval and constrains the age of the lower Logan Formation as no younger than the Lower typicus Global Conodont Biozone (Lane et al., 1980), which is equivalent to Tournaisian 'Tn3a' and lower 'Tn3b', and the lower Osagean Series. Consequently, it seems inescapable that the bulk of the Cuyahoga Formation is unequivocally upper Kinderhookian and equivalent to the Tournaisian 'Tn2c'.

Overlooked in most discussions of age assignments for this interval is the significance of the Rushville Shale that overlies the Logan Formation in central Ohio (Manger 1971a, 1979; Thompson et al., 1971). A dolomitic limestone at the base of this unit has yielded conodonts unequivocally representing the anchoralis-latus Global Conodont Biozone (Lane et al., 1980) (originally assigned to the Doliognathus latus Subzone, Bactrognathodus-Pseudopolygnathus multistriatus Conodont Zone by Thompson et al., 1971). This global conodont zone is equivalent to upper Tournaisian 'Tn3c' and the lower Osagean Series, further supporting the contention that the upper Logan Formation can be no younger than the lower Osagean Series, and that the bulk of the Cuyahoga Formation, including the famous Sciotoville Bar ammonoid occurrence (Manger, 1971b), must be Kinderhookian.

\section{SYSTEMATIC PALYNOLOGY}

Subturma Zonotriletes Waltz, 1935

Infraturma Auriculati Schopf emend. Dettmann, 1963

Genus Mooreisporites Neves, 1958

Type species. Mooreisporites fustis Neves, 1958

Mooreisporites streelii sp. nov.

1993 cf. Mooreisporites sp. Playford \& McGregor, pl. 15, fig. 1

Diagnosis. Trilete, acamerate miospores. Amb triangular with convex, straight or slightly concave sides and rounded apices. Trilete mark distinct; suturae straight, simple, extend almost to the equator. Exine moderately thin. Proximal surface laevigate. Apices variably thickened, ornamented by irregular bacula which often coalesce to form irregular projections. Distal surface smooth to ornamented by bacula or irregular ridges.

Holotype. Plate 2, fig. 1. Trinity College Dublin Geological Museum, specimen catalogue number TCD 47502, slide 1(3), England Finder co-ordinates E 47/4.

Type locality and horizon. Medal Brick and Tile Company Quarry, Wayne County, Ohio, USA. Sample 1, Wooster Member, Cuyahoga Formation.

Description. Specimens variable in terms of shape of amb and density and distribution of ornament. Exine 1-2 $\mu \mathrm{m}$ thick. Bacula at the apices up to $3 \mu \mathrm{m}$ high and $3 \mu \mathrm{m}$ in basal diameter; flat-topped to rounded in profile, often coalescing to form irregular projections. On a single specimen, the density of ornament may vary greatly between the three apices. Distal ornament also variable, consisting of bacula and ridges similar to those at the apices but generally lower; often concentrated around the distal pole from where it may extend to join with the ornament at one, two or all three of the apices. Non-polar compressions common.

Dimensions. 54 (61) $75 \mu \mathrm{m}, 15$ specimens, sample 1 (Medal Brick and Tile Company Quarry).

Comparisons. Mooreisporites streelii sp. nov. can be distinguished from other species by its size, shape of amb and variable ornament. Assignment of this taxon to the genus Mooreisporites is arbitrary since some specimens possess large thickenings at the apices similar to those which characterize the genera Tripartites and Triquitrites.

\section{ACKNOWLEDGEMENT}

B. Owens publishes with the permission of the Director, British Geological Survey (NERC).

\section{Manuscript received April 1997 \\ Manuscript accepted April 1998}




\section{REFERENCES}

Andrews, E. B., 1870. Report of progress in the second district. Ohio Geological Survey, Report of Progress for 1869, 53-135

Briggs, C., Jr 1838. Report (Scioto and Hocking Valleys). In Mather, W. W. (Ed.) First Annual Report, Ohio Geological Survey, 71-98.

Chaplin, J. R., 1979. Upper Devonian-Lower Carboniferous stratigraphy of the Morehead, Kentucky Area. In Ettensohn, F. R. \& Dever, G. R., Jr (Eds) Carboniferous geology from the Appalachian Basin to the Illinois Basin through eastern Ohio and Kentucky. Ninth International Congress on Carboniferous Stratigraphy and Geology, Urbana, Illinois, 1979, Guidebook Field Trip 4, 130-132.

Chaplin, J. R. \& Mason, C. E. 1979. Stop 3: The DevonianCarboniferous boundary. In Ettensohn, F. R. \& Dever, G. R., Jr (Eds) Carboniferous geology from the Appalachian Basin to the Illinois Basin through eastern Ohio and Kentucky. Ninth International Congress on Carboniferous Stratigraphy and Geology, Urbana, Illinois, 1979, Guidebook Field Trip 4, 152-162.

Clayton, G., Coquel, R., Doubinger, J., Gueinn, K. J., Loboziak, S., Owens, B. and Streel, M. 1977. Carboniferous miospores of Western Europe; illustration and zonation. Mededelingen Rijks Geologische Dienst, 29: 1-71.

Coleman, U. \& Clayton, G. 1987. Palynostratigraphy and palynofacies of the uppermost Devonian and lower Mississippian of eastern Kentucky (U.S.A.), and correlation with Western Europe. Courier. Forsch.-Inst. Senckenberg, 98: 75-93.

Collins, H. R., 1979. The Mississippian and Pennsylvanian (Carboniferous) Systems in the United States - Ohio. U.S. Geological Survey, Professional Paper, 1110-E: E1-E26.

Collinson, C., Rexroad, C. R. \& Thompson, T. L. 1971. Conodont zonation of the North American Mississippian. In Sweet, W. C. \& Bergstrom, S. (Eds) Symposium on Conodont Biostratigraphy. Geological Society of America, Memoirs 127: 353-395.

DeWitt, W., Jr 1970. Age of the Bedford Shale, Berea Sandstone, and Sunbury Shale in the Appalachian and Michigan Basins, Pennsylvanian, Ohio, and Michigan. U.S. Geological Survey, Bulletin 1294G: G1G11.

Gordon, M., Jr 1986. Late Kinderhookian (Early Mississippian) ammonoids of the western United States. Journal of Paleontology, Memoirs 19, Vol. 60, Supp. 3: 36.

Gordon, M., Jr \& Mason, C. E. 1985. Progradation of the Borden Formation in Kentucky, U.S.A. demonstrated by successive Early Mississippian (Osagean) ammonoid faunas. Compte rendu, Tenth International Congress on Carboniferous Stratigraphy and Geology, Madrid, 1983, 1: 191-198.

Hass, W. H. 1947. Conodont zones in Upper Devonian and Lower Mississippian formations of Ohio. Journal of Paleontology, 21(2): 131141.

Hicks, L. E. 1878. The Waverly Group in central Ohio. American Journal of Science, 3rd Series, 16: 216-224.

Higgs, K., Clayton, G. \& Keegan, J. B. 1988. Stratigraphic and systematic palynology of the Tournaisian of Ireland. Special Paper, Geological Survey of Ireland, 7: 1-82.

Holden, F. T. 1942. Lower and Middle Mississippian stratigraphy of Ohio. Journal of Geology, 50(1): 34-67.

Lane, H. R., Sandberg, C. A. \& Ziegler, W. 1980. Taxonomy and phylogeny of some Lower Carboniferous conodonts and preliminary standard post-Siphonodella zonation. Geologie et Paleontologie, 14 (3): $117-164$.

Manger, W. L. 1971a. The Mississippian ammonoids Karagandoceras and Kazkhstania from Ohio. Journal of Paleontology, 45(1): 33-39.

Manger, W. L., 1971b. The position and age of the Sciotoville bar locality, southern Ohio. Ohio Journal of Science, 71(5): 284-291.

Manger, W. L., 1979. Lower Carboniferous ammonoid assemblages from North America. Compte rendu, Eighth International Congress on Carboniferous Stratigraphy and Geology, Moscow, 1975, 3: 211-221.

Molyneux, S. G., Manger, W. L. \& Owens, B. 1984. Preliminary account of Late Devonian palynomorph assemblages from the Bedford Shale and Berea Sandstone formations of central Ohio, U.S.A. Journal of Micropalaeontology, 3 (2): 41-51.

Newberry, J. S., 1870. Report of progress of the geological survey in Ohio in 1869. Ohio Geological Survey, Report of Progress for 1869, 153.

Patchen, D. G., Avary, K. L. \& Erwin, R. B., 1985a. Northern Appalachian region (chart). Correlation of Stratigraphic Units of North America (COSUNA) Project, American Association of Petroleum Geologists.

Patchen, D. G., Avary, K. L. \& Erwin, R. B. 1985b. Southern Appalachian region (chart). Correlation of Stratigraphic Units of North America (COSUNA) Project, American Assaciation of Petroleum Geologists.

Playford, G. \& McGregor, D. C. 1993. Miospores and organic-walled microphytoplankton of Devonian-Carboniferous boundary beds (Bakken Formation), southern Saskatchewan: a systematic and stratigraphic appraisal. Geological Survey of Canada Bulletin, 45, 107.

Sandberg, C. A., Ziegler, W., Leuteritz, K. \& Brill, S. M., 1978. Phylogeny, speciation and zonation of Siphonodella (Conodonta, Upper Devonian and Lower Carboniferous). Newsletters on Stratigraphy, 7(2): 102-120.

Shaver, R. H. 1985, Midwestern basin and arches region (chart). Correlation of Stratigraphic Units of North America (COSUNA) Project, American Association of Petroleum Geologists.

Streel, M. \& Traverse, A. 1978. Spores from the Devonian Mississippian transition near the Horseshoe Curve Section, Altoona, Pennsylvania, U.S.A. Revue of Palaeobotany and Palynology, 26: 21-30.

Szmuc, E. J. 1957. Stratigraphy and paleontology of the Cuyahoga Formation of northern Ohio. Unpublished dissertation, Ohio State University.

Szmuc, E. J. 1970. The Mississippian system. In Banks, P. O. \& Feldmann, R. M. (Eds) Guide to the Geology of Northeastern Ohio. Northern Ohio Geological Society.

Thompson, T. L., Ford, N. S. \& Sweet, W. C. 1971. Conodonts from the Rushville Formation (Mississippian) of Ohio. Journal of Paleontology, 45(4): 704-712.

Weller, J. M. (chairman), Williams, J. S., Bell, W. A., et al. 1948. Correlation of the Mississippian Formations of North America. Bulletin of the Geological Society of America, 59(1): 91-196.

Warg, J. B. \& Traverse, A. 1973. A palynological study of shales and 'coals' of a Devonian - Mississippian transition zone, central Pennsylvania. Geoscience and Man, 7: 39-46.

Winslow, M. R. 1962. Plant spores and other microfossils from Upper Devonian and Lower Mississippian rocks of Ohio. U.S. Geological Survey Professional Paper, 364: 1-93. 